\title{
Effect of drying on selected proximate composition of fresh and processed fruits and seeds of two pumpkin species
}

\author{
${ }^{1,3,4}$ Fedha, M.S., ${ }^{1}$ Mwasaru, M.A., ${ }^{1}$ Njoroge, C. K, ${ }^{1}$ Ojijo, N. O and ${ }^{2,3}$ Ouma, G. O. \\ ${ }^{1}$ Department of Food Science And Technology,JomoKenyatta University Of Agriculture and \\ Technology,P.O BOX 62000,Nairobi,Kenya \\ ${ }^{2}$ Associate Professor Of Hoticulture,School Of Agriculture,Food Security and \\ Biodiversity,Bondo University College,P.O Box 210-40601 Bondo,Kenya \\ ${ }^{3}$ Corresponding authors:monicafedha@yahoo.co.uk,goumaoindo@yahoo.com \\ ${ }^{4}$ Present address:Ministry Of Agriculture,Kisumu West District,P.O Box Paw- \\ Akuche,Kisumu,Kenya \\ ABSTRACT
}

\begin{abstract}
Studies were conducted at Jomo Kenyatta University of Agriculture and Technology, Kenya to investigate the effect of drying on the proximate composition of crude fibre, crude fat and carbohydrates of two species of pumpkins namely, C. moschata and C. maxima in the year 2006. the treatments comprised fruits with rind and those without rind (fruit pulp), whole seeds and seed kernels, and raw and dry samples (flour). The experimental design was completely randomized and data analysis was by Genstat package. Proximate composition of raw $C$. moschata fruit with rind was $87.9 \%$ moisture (fresh weight), $4.9 \mathrm{~g} / 100 \mathrm{~g}$ crude protein and $6.7 \mathrm{~g} / 100 \mathrm{~g}$ crude ash. The corresponding values of $C$. maxima were $87.0 / 100 \mathrm{~g}, 3.9 \mathrm{~g} / 100 \mathrm{~g}$ and $6.9 \mathrm{~g} / 100 \mathrm{~g}$ on dry weight basis. $C$. moschata with rind contained significantly $(P<0.05)$ higher crude fat than $C$. moschata seeds. The results also showed that there was significantly $(P<0.05)$ more crude protein in $C$. maxima than C. moschata. Similar results were obtained for moisture content. The conclusion is that pumpkin seeds are rich in protein and both species of pumpkin contain high moisture content in their fruits, yielding a dry matter of approximately $12 \%$ on dehydration. Pumpkin seeds contain low moisture levels of $5.7 \%-6.1 \%$ making them be stored for longer duration.Pumpkin seeds are a better source of protein hence contributes substantially to the dietary human nutrition. Crude ash content of pumpkin fruits was higher than that for seeds showing that mineral intake in the diet can be enhanced by increasing the consumption of pumpkin fruits.
\end{abstract}

Keywords: Crude, Proximate, analysis, pumpkin, fruit, seed, moisture, drying, nutrition.

\section{INTRODUCTION}

The pumpkin is an angiosperm belonging to the cucurbitaceae family that is characterized by prostrate or climbing herbaceous vines with tendrils and large, fleshy fruits containing numerous seeds (Acquaah, 2004). Pumpkin of the genus C. maxima is also called squash guard. It originated from South America, possibly Peru and now widely distributed throughout the tropics (Tindall, 1983). Its fruits are large, variable in shape, round or oblong, covered with small raised spots weighing $2-5 \mathrm{~kg}$. The rind may be soft or hard, sometimes brightly coloured. The flesh is yellow and the seeds are white or brown (Tandall, 1983). C. moschata is closely related to $C$. maxima. Its other names are winter squash or butternut squash. Its origin is tropical South or Central America. It is the most widely grown species of cucurbitaceae. It is generally lacking in bristly hairs on leaves and stems which mainly distinguish it from C. maxima (Rice, 1973, Tindall, 1983). The flesh of the fruit is yellow to orange and the seeds are either white or brown in colour. C. moschata is more tolerant to harsh environmental conditions than other cucurbitaceae species.

The varieties of pumpkin grown in Kenya are of the species C. moschata (butternut squash) and $C$. maxima (squash pumpkin). The pumpkin has great economic potential as a food and as an industrial crop. It is utilized for its leaves, marrow, fruit pulp and seeds. The stem could be used as livestock feed. It has health enhancing properties. Its cultivation and utilization in Kenya follows the rich ecological, cultural and ethnic diversity of the country (Chweya and Eyzaguirre, 1999). Due to its bulkiness there is need 
to investigate the various utilization options. The present study investigated the effect of drying on the proximate composition of two species of pumpkin namely: C. maxima and C. moschata

\section{MATERIALS AND METHODS}

The research involved dehydrating two species of pumpkin (C. moschata and C. maxima) and grinding them into flour for proximate analysis. The treatments involved fresh and dry samples, fruit with rind and without rind (pulp), whole seeds and seed kernels. For each treatment, three pumpkins were analyzed in duplicate. A completely randomized design (CRD) was employed in the study. The pumpkins were sourced from farmers in Machakos District, Kenya. Selection of the pumpkin fruit samples was based on maturity. Fully ripe pumpkins were used in the study. They were stored at a temperature of $10^{\circ} \mathrm{C}$ before analysis.

Moisture content was determined by AOAC method 930.04; (AOAC, 1995) total ash by AOCC method 930.05 and crude protein $(\mathrm{N} \% \times 0.25)$ BY AOAC method 978.04 (AACC 1995).

To make flour from pumpkin fruit, fresh mature pumpkins of C. moschata and C. maxima species were cleaned, peeled (some fruits were not peeled), seeds removed and chopped into pieces of $2.5 \mathrm{~cm}$ in length and $0.31 \mathrm{~cm}$ thick using a motorized electric chipper (model skymsen PA-TC, Brazil). Different known weights of slices were subjected to blanching before drying.

Drying was done using an electric drier (KIDRI EDSC Division, Nairobi) to a moisture content of $10 \%$. This was achieved by drying at a temperature of $49^{\circ} \mathrm{C}$ for 4 hours. Dried fruits were then ground into flour using a fine mill (Model Bauermeister, Hamburg, Attona, Germany) after which flour samples were subjected to proximate analysis.

Flour from seed kernels was obtained by the method described by El-Adawy and Tara (2001). Pumpkins were cut by a sharp knife and the seeds hand collected and washed with water then oven dried at $60^{\circ} \mathrm{C}$ for 12 hours using an Isuzu hot air rapid drying oven (Soyokaze type ASF - 113S). The dried seeds were shelled to remove the kernels, which were ground to pass through a 60 mesh (British Standard Screen). The fine flour of the whole seeds and seed kernels were put in an air tight jar and kept in a refrigerator $\left(10^{\circ} \mathrm{C}\right)$ until analysis.
Analysis of variance (ANOVA) was done using the Genstat Discovery $5^{\text {th }}$ edition (Roger et al 2001) at a $5 \%$ significance level.

\section{RESULTS AND DISCUSSION}

\section{Proximate composition of fresh and processed pumpkin fruits and seeds}

Moisture content of fruits and seeds: The moisture content of fruits and seeds in the present study is shown in Table 1 . The results showed that there were significant $(P<0.05)$ differences between moisture content of fruits with rind and those without rind for both species. The latter were found to contain less moisture. Table 1also presents the moisture contents of seeds and seed kernels of pumpkins. A one way analysis of variance showed that there were no significant $(P<0.05)$ difference between moisture levels of sun dried seeds and seed kernels for the $C$. moschata species and the inverse was true for the $C$. maxima species.

These values for dry seeds are similar to those obtained by Kershaw and Hackett, (1987) for other edible oil seeds such as cotton seeds (6.46\%), peanuts $(4.58 \%)$, palm kernel $(5.31 \%)$, sesame $(4.60 \%)$ and sunflower seeds (6.58\%). They are lower than those of soybean (11.07\%) and coconut seeds, (14.3\%) (FAO, 1982). The low levels of moisture of pumpkin seeds enable them to be preserved for long periods

Table 1: Moisture content of fruit vegetables and seeds of two pumpkin species

(\% d.w)

\begin{tabular}{|l|l|l|}
\hline Treatment & C. moschata & C. maxima \\
\hline Fruit with rind & $87.9 \pm 0.0^{\mathrm{d}}$ & $87.1 \pm 0.2^{\mathrm{e}}$ \\
\hline Fruit without rind & $89.5 \pm 0.3^{\mathrm{e}}$ & $88.2 \pm 0.4^{\mathrm{f}}$ \\
\hline Whole seed ( fresh) & $33.2 \pm 0.4^{\mathrm{c}}$ & $34.1 \pm 0.1^{\mathrm{d}}$ \\
\hline Seed kernel ( fresh) & $28.5 \pm 0.9^{\mathrm{b}}$ & $30.9 \pm 0.1^{\mathrm{c}}$ \\
\hline Whole seed (sun dried) & $5.7 \pm 0.4^{\mathrm{a}}$ & $6.1 \pm 0.1^{\mathrm{b}}$ \\
\hline Seed kernel (sun dried) & $5.6 \pm 0.0^{\mathrm{a}}$ & $5.5 \pm 0.2^{\mathrm{a}}$ \\
\hline L.S.D. $(\mathrm{P}<0.05)$ & 0.9 & 0.4 \\
\hline
\end{tabular}

Values are mean \pm S.D, $\mathrm{n}=3$

${ }^{a-f}$ Values in the same column with different superscripts are significantly different at $5 \%$ level.

Moisture levels of food products have a bearing on their dry matter content. The higher the moisture content the lower the dry matter yield on drying. Therefore information on moisture content would help the food processors to make decisions on the economics of thermal processing of the foods. 
Crude protein content of raw and dried pumpkin fruits and seeds: The protein content of fruits and seeds of pumpkins studied are presented in Table 2. One way ANOVA showed that no significant $(P<$ 0.05 ) difference exist between protein contents of raw and dry samples for fruit with ring of the C.moschata species. For the other treatments it was found that drying and grinding either reduced or increased the protein content of the samples. Seed kernels contained higher protein than C. moschata seed kernels. The values obtained for whole seeds are similar to those of Achu et al. (2005) who reported them to contain 29-35\%. Martin (1998) got 35\%, which were higher than cashew nuts $(22.8 \%)$ and sesame (18.8\%). The fluted pumpkin (Telfaira occidentals) seed was reported to contain $30.1 \mathrm{~g} / 100 \mathrm{~g}$ protein (Asiegbu, 1987).

Table 2: Crude protein content of raw and processed samples of fruits and seeds of two species of pumpkins (g/100g d.w)

\begin{tabular}{|l|l|l|l|l|l|}
\hline Treatment & Raw samples & & \multicolumn{2}{l|}{ Dry samples } & L.S.D. \\
& C. moschata & C. maxima & C. moschata & C. maxima & P<0.05 \\
\hline Fruit with rind & $4.9 \pm 0.2^{\mathrm{c}}$ & $3.9 \pm 0.1^{\mathrm{a}}$ & $4.9 \pm 0.0^{\mathrm{c}}$ & $4.0 \pm 0.0^{\mathrm{b}}$ & 0.1 \\
\hline Fruit without rind & $4.0 \pm 0.1^{\mathrm{c}}$ & $3.6 \pm 0.0^{\mathrm{a}}$ & $4.3 \pm 0.0^{\mathrm{d}}$ & $3.7 \pm 0.0^{\mathrm{b}}$ & 0.1 \\
\hline Whole seed & $36.2 \pm 0.3^{\mathrm{c}}$ & $35.8 \pm 0.1^{\mathrm{b}}$ & $35.4 \pm 0.3^{\mathrm{a}}$ & $36.3 \pm 0.2^{\mathrm{c}}$ & $0.3^{\mathrm{m}}$ \\
\hline Seed kernel & $37.7 \pm 0.3^{\mathrm{a}}$ & $39.5 \pm 0.2^{\mathrm{c}}$ & $37.4 \pm 0.2^{\mathrm{a}}$ & $40.3 \pm 0.3^{\mathrm{b}}$ & 0.4 \\
\hline
\end{tabular}

Values are mean \pm S.D, $\mathrm{n}=3$

${ }^{a-d}$ Values in the same row with different superscripts are significantly different at $5 \%$ level

An adult male of about $70 \mathrm{~kg}$ body weight requires $35 \mathrm{~g}$ of protein daily, therefore, only $98.93 \mathrm{~g}$ of C.moschata seed would be required to provide the minimum daily protein need. However, $122 \mathrm{~g}$ should be consumed to meet the requirement; if an allowance of $25 \%$ is made to take care of digestibility and the limiting sulphur amino acid (Fagbemi and Oshodi, 1991).

The proteins are of the globulin type and are deficient in lysine and sulphur bearing amino acids (Vodsuhe and Capo-Chichi, 1998). The results show that these Kenyan species of pumpkins are rich in proteins hence good for children, lactating mothers and old people who need more proteins for growth, maintenance and repair of warn out tissues.
Crude ash content of raw and processed pumpkin fruits and seeds: The total ash content of the fruits and seeds in the present study is presented in in Table 3. No significant differences were observed between species and between raw and dry samples of whole seeds and seed kernels. Fruits were found to have significantly $(P<0.05)$ higher crude ash content than the seeds and seed kernels. Fruit with rind had significantly higher crude ash content than the fruit pulp. Values for seeds and kernels are similar to those obtained by Achu et al (2005) which ranged from 3.5-5.3\%. These values are similar to those of soybean (5.0\%), cotton seed $(4 \%)$, sesame $(3.8 \%$ and sunflower seed (4.1\%) (FAO, 1982).

Table 3: Crude ash content of raw and processed fruits and seeds of pumpkin (g/100g d.w)

\begin{tabular}{|c|c|c|c|c|c|}
\hline Treatment & Raw Samples & & Flour Samples & & L.S.D. \\
\hline & C. moschata & C. maxima & C. moschata & C. maxima & $(P<0.05)$ \\
\hline Fruit with rind & $6.7 \pm 0.1^{a}$ & $6.9 \pm 0.3^{\mathrm{ab}}$ & $7.1 \pm 0.2^{\mathrm{bc}}$ & $6.8 \pm 0.1^{\mathrm{ac}}$ & 0.3 \\
\hline Fruit pulp & $5.9 \pm 0.1^{b}$ & $6.5 \pm 0.1^{c}$ & $5.6 \pm 0.4^{\mathrm{a}}$ & $5.9 \pm 0.1^{b}$ & 0.2 \\
\hline Whole seed & $4.0 \pm 0.1^{b c}$ & $3.7 \pm 0.3^{a}$ & $4.1 \pm 0.3^{\mathrm{C}}$ & $3.7 \pm 0.4^{\mathrm{a}}$ & 0.2 \\
\hline Seed kernel & $4.4 \pm 0.4^{b c}$ & $4.1 \pm 0.1^{\mathrm{a}}$ & $4.4 \pm 0.2^{c}$ & $4.3 \pm 0.1^{\mathrm{ab}}$ & 0.2 \\
\hline
\end{tabular}

Values are mean \pm S.D, $\mathrm{n}=3$ 


\section{CONCLUSION:}

From the present study, it can be concluded that both species of pumpkins contain high moisture levels, with fruits yielding a dry matter of approximately $12 \%$ on dehydration. Conversely, the pumpkin seeds contain low moisture levels (5.7\%-6.1\%). Therefore the seeds can be stored over long periods, owing to their low moisture levels.

The pumpkin seeds are better sources of protein than the pumpkin fruits since the fruits contain relatively low amounts of proteins (4-4.9\%) as compared to the seeds (35-40\%). The crude ash content of pumpkin fruits was found to be higher than that for the seeds, with fruits ranging between $5-7 \%$ while seeds 3.6$4.4 \%$, therefore mineral intake in the diet can be enhanced by increased consumption of pumpkin fruits.

\section{REFERENCES}

Achu,B.M, Fokou, E, Martin, F (2005) Nutritive value of some curcubitaceae oil seeds from different regions in Cameroon. African Journal of biotechnology 4:1329 1334.

Acquaah, G (2004) Horticulture: principles and Practices $3^{\text {rd }}$ edition Upper saddle River: New Jersey, Pearson Education Inc.

AOAC (1995) Official methods of analysis of the Association of official Analytical Chemists $10^{\text {th }}$ Edition VOL.II Washington, DC, U.S.A.
Asiegbu, J. E (1987) Some biochemical evaluation of fluted pumpkin seed. Journal of the Science of Food and Agriculture 40:151-155.

Chweya, J. A and P. B. Eyzaguirre (1999) The Biodiversity of Traditional Leafy Vegetables. International Plant Genetic Resources Institute, Rome, Italy.

El-Adawy, T. A and Taha, K. M (2001) Characteristics and compositions of different seed oils and flours. Food chemistry 74:47-54

Fagbemi, T. N and Oshodi, A. A (1991) Chemical composition and functional properties of full fat fluted pumpkin seed flour. Nigerian Food Journal 9: 26-32

FAO(1982) Food Composition Table for the Near East. Nuts and Seeds. FAO Food and Nutrition paper 26 ISBN 92 - 5- 10177 - 6 P.85

Martin, F (1998) Cucurbit seeds as possible oil and protein sources for small scale household use in the hot humid tropics. Oil crops/processing, P.2

Rice, R. P (1973). Fruits and vegetable production in warm climates. London: Macmillan Press PP 252-255.

Roger, S, Gillian, A, Ric, C and Buysee, W (2001) Using Genstat for Windows $5^{\text {th }}$ edition in Agriculture and Experimental Biology. ICRAF, Nairobi, Kenya.

Tindall, H. D (1983) Vegetables in the Tropics Macmillan Hong Kong pp 146 - 167

Vodouhe, S. R and Capo-chichi, L (1998) Eguusi; High protein crop with Multiple uses but neglected and underutilized. Bulletin-CIEPA/West Africa Cover Crops./ Cotonon, Republic of Benin p.6 